\title{
Distribution of native and exotic branchiobdellidans (Annelida: Clitellata) on their respective crayfish hosts in northern Italy, with the first record of native Branchiobdella species on an exotic North American crayfish
}

\author{
Stuart R. GELDER*, Giovanni B. DELMASTRO ${ }^{1)}$ and Joy N. RAYBURN \\ Department of Science, University of Maine at Presque Isle, Maine 04769-2888, U.S.A. \\ ${ }^{1)}$ Museo Civico di Storia Naturale, Cascina Vigna, Cas. Post. 89, I-10022 Carmagnola, TO, Italy \\ *e-mail corresponding author: GELDER@ polaris.umpi.maine.edu
}

\begin{abstract}
Branchiobdellidans were found on crayfish at the 18 sites examined in northern Italy. At 15 of the sites the native crayfish, Austropotamobius pallipes, was collected and all supported specimens of Branchiobdella italica. A few specimens of $\mathrm{B}$. parasita were found at only two of these sites and no specimens of $\mathrm{B}$. hexodonta were observed during the survey. The North American Louisiana red swamp crayfish, Procambarus (Scapulicambarus) clarkii has been found in three additional sites around Carmagnola, south of Torino. The exotic Cambarincola mesochoreus was recovered from red crayfish at two sites. However, no specimens of $\mathrm{C}$. mesochoreus were found at the third site, but specimens B. italica and B. parasita were identified. This is the first record of native Branchiobdella spp. on an exotic and wild crayfish in northern Italy.
\end{abstract}

Key words: Branchiobdellidans, Clitellata, Annelida, exotic crayfish, distribution, northern Italy

\section{INTRODUCTION}

Over the last 150 years species of the native Branchiobdella have been reported across central and eastern Europe extending from France, northern Italy and the Balkans in the south to southern Scandinavia and adjacent Russia in the North (Pop 1965; van der Land 1978). This distribution was based on many national studies of branchiobdellidans including those from Yugoslavia (Karaman 1970), Poland (Wojtas 1964), Bulgaria (Kosarov et al. 1972), Slovakia (Halgoš 1972), Ukraine (Boshko 1983), Hungary (Subchev 1984), Estonia and Finland (Timm 1987), and, southern Germany and Austria (Nesemann 1994). Recent studies have reported the presence of exotic North American species of branchiobdellidans in Europe following the importation of their crayfish hosts into Sweden (Franzén 1962) and northern Italy (Gelder et al. 1994).

Branchiobdellidans were first reported in northern Italy by Mazzarelli (1903) and again in 1906 when he identified Branchiobdella pentodonta Whitman, 1882 on the crayfish, Potamobius pallipes Lereboullet, 1858 (= Austropotamobius pallipes) in the Milan Aquarium. The branchiobdellidans were blamed for damaging the gills and blocking the respiratory water flow to the gills, resulting in a detrimental condition call "branchiobdellosi" (Mazzarelli 1903, 1906). Pierantoni (1906a, b) described the anatomy of B. pentodonta and Branchiobdella astaci Odier, 1823 found on crayfish he called "Astacus pallipes" from Lombardia. The high mortality of crayfish in the Milan Aquarium in 1928 resulted in the specimens being thoroughly examined by Canegallo (1928) who discovered branchiobdellidans on the cru- staceans. Her detailed examination of the branchiobdelldan's anatomy led her to reject the earlier identification of $B$. pentodonta and described them as a new species, Branchiobdella italica Canegallo, 1928. The new species had many characteristics in common with $B$. pentodonta and some subsequent workers believed $B$. italica to be a junior synonym or subspecies of the former (Gelder 1996). We follow the rationale given in Gelder et al. (1994) and continue to recognize B. italica as a valid species.

This study was designed to extend the restricted number of reports of branchiobdellidans in areas of northern Italy given by Gelder et al. (1994) and Nobile et al. (1994, 1995). The additional information on the distribution of both native and endemic branchiobdellidans and $A$. pallipes in the northwestern region will assist in monitoring the spread and effects of the exotic North American Cambarincola mesochoreus Hoffman, 1963 on the Louisiana red swamp crayfish, Procambarus (Scapulicambarus) clarkii (Girard 1952).

\section{MATERIALS AND METHODS}

Branchiobdellidans were removed from their crayfish host in Italy by G.B. Delmastro and associates, and placed directly into individual vials containing $70 \%$ or $100 \%$ ethanol. Subsequently, the number of branchiobdellidans in each vial was estimated, and representatives were prepared for microscopical examination in the Department of Science, University of Maine at Presque Isle, U.S.A. by S.R. Gelder and J.N. Rayburn. The preparation method consisted of specimens being dehydrated in graded ethanol solutions, cleared in methyl salicylate, infiltrated with Canada balsam and 
Tab. 1. Distribution of branchiobdellidans and their crayfish hosts from selected sites designated by their province and region in northern Italy.

Abbreviations: B. = Branchiobdella; C. = Cambarincola; P.(S.) = Procambarus (Scapulicambarus); A. = Austropotamobius. Detailed location of collection sites: ${ }^{1}$ Pelago, T. Vicano at Ferrano (alt. $500 \mathrm{~m}$ a.s.1.); ${ }^{2}$ Fiorano Modenese, T. Fossa at Nirano (alt. $200 \mathrm{~m}$ a.s.l.); ${ }^{3}$ Pellegrino Parmense, T. Rivarolo at Iggio (alt. $450 \mathrm{~m}$ a.s.l.); ${ }^{4}$ Morfasso, a stream tributary of T. Arda at Casale (alt. $550 \mathrm{~m}$ a.s.1.); ${ }^{5}$ Villalvernia, locality Molino dell'Edificio; ${ }^{6}$ Cantarana, Rio Marrone (alt. 175 m a.s.1.); ${ }^{7}$ Bagnasco, Rio di Val Garbenna (alt. $500 \mathrm{~m}$ a.s.l.); ${ }^{8}$ Frabosa Sottana, Rio Secco at San Giacomo (alt. 600 m a.s.1.); ${ }^{9}$ Barge, Rio Battibò at Mondarello (alt. $415 \mathrm{~m}$ a.s.1.); ${ }^{10}$ Luserna San Giovanni, stream near Incubatoio Ittico Provinciale; ${ }^{11}$ Avigliana, Rio Freddo (alt. $335 \mathrm{~m}$ a.s.1.); ${ }^{12}$ Trana, Naviglio di Trana, Torbiera; ${ }^{13}$ Balangero, T. Banna, bridge near Madonna dei Martiri; ${ }^{14}$ Rocca Canavese, Rio dell'Osio (alt. $445 \mathrm{~m}$ a.s.1.); ${ }^{15}$ Carmagnola, Canale di San Grato, Martinetto (alt. $238 \mathrm{~m}$ a.s.1.); ${ }^{16}$ Carmagnola, Rio Venesima di Fortepasso, C.na Timavo; ${ }^{17}$ Ceresole d'Alba, a pond near Cascina Italia (alt. $280 \mathrm{~m}$ a.s.1.); ${ }^{18}$ Casalgrasso, River Po, inflow of River Varaita (alt. 240 m a.s.1.).

\begin{tabular}{|c|c|c|c|c|}
\hline Branchiobdellidan & Crayfish & Location & Date & Collector(s) \\
\hline B. italica & A. pallipes & ${ }^{1}$ Firenze $(\mathrm{T})$ & 15 Jul. 1996 & Iaconelli \\
\hline B. italica & A. pallipes & ${ }^{2}$ Modena (E-R) & 14 Jul. 1996 & Iaconelli \\
\hline B. italica & A. pallipes & ${ }^{3}$ Parma (E-R) & 13 Jul. 1996 & Iaconelli \\
\hline B. italica & A. pallipes & ${ }^{4}$ Piacenza (E-R) & 13 Jul. 1996 & Iaconelli \\
\hline B. italica & A. pallipes & ${ }^{5}$ Alessandria $(\mathrm{P})$ & 30 May 1996 & Andreani \& Iaconelli \\
\hline B. italica & A. pallipes & ${ }^{6}$ Asti (P) & 1 Aug. 1994 & Delmastro \\
\hline B. italica & A. pallipes & ${ }^{7}$ Cuneo $(\mathrm{P})$ & 8 Aug. 1997 & Delmastro \& Evangelista \\
\hline B. italica & A. pallipes & ${ }^{8}$ Cuneo $(\mathrm{P})$ & 18 Jun. 1996 & Delmastro \\
\hline B. italica & A. pallipes & ${ }^{9}$ Cuneo $(\mathrm{P})$ & 20 Jun. 1996 & Delmastro \\
\hline B. parasita & A. pallipes & & & \\
\hline B. italica & A. pallipes & ${ }^{10}$ Torino $(\mathrm{P})$ & 10 Nov. 1995 & Delmastro \& Iaconelli \\
\hline B. italica & A. pallipes & ${ }^{11}$ Torino $(\mathrm{P})$ & 31 May 1996 & Andreani, Delmastro \& Iaconelli \\
\hline B. parasita & A. pallipes & & & \\
\hline B. italica & A. pallipes & ${ }^{12}$ Torino $(\mathrm{P})$ & 4 Oct. 1991 & Delmastro \& others \\
\hline B. italica & A. pallipes & ${ }^{13}$ Torino $(\mathrm{P})$ & 16 Jul. 1990 & Avalle \& Delmastro \\
\hline B. italica & A. pallipes & ${ }^{14}$ Torino $(\mathrm{P})$ & 31 May 1996 & Andreani, Delmastro \& Iaconelli \\
\hline B. italica & P.(S.) clarkii & ${ }^{15}$ Torino $(\mathrm{P})$ & 7 Aug. 1997 & Delmastro \& Evangelista \\
\hline B. parasita & P.(S.) clarkii & & & \\
\hline C. mesochoreus & P.(S.) clarkii & ${ }^{16}$ Torino $(\mathrm{P})$ & 23 Feb. 1990 & Delmastro \\
\hline C. mesochoreus & P.(S.) clarkii & ${ }^{17}$ Cuneo (P) & 29 Aug. 1996 & Delmastro \& Giovenino \\
\hline B. italica & A. pallipes & ${ }^{18}$ Cuneo (P) & 14 Dec. 1992 & Turletti \\
\hline
\end{tabular}

mounted on slides under a coverslip. Four to six specimens were prepared from each vial unless it appeared more than one species might be present, and in these cases up to ten specimens were examined.

Crayfish were collected from 17 sites in northern Italy and one in an adjacent area of Tuscany, central Italy. The location and approximate altitude of the sites, date of collection and name of the collector(s), are given in table 1 so that any future collections can be made and the results compared with this base-line study.

\section{RESULTS}

The species of branchiobdellidans and their hosts were identified from 18 sites in this survey and the information tabulated in table 1 . The survey started in the Apennine Range with site 1 near Firenze, then progressed westwards (sites 2 to 6 ) with the remaining sites in the Maritime Alps of Piemonte (Fig. 1). The native crayfish, A. pallipes, was collected from 15 of the 18 sites sampled, and at each of these 15 sites specimens of $B$. italica were reported on the crayfish. Specimens of $B$. parasita were less numerous and restricted to two sites
(9 \& 11) in western Piemonte, and no specimens of $B$. hexodonta were found.

The North American red crayfishes, P.(S.) clarkii, carrying C. mesochoreus, were found at site 16 in Carmagnola, and site 17 at Ceresole Alba, $8 \mathrm{~km}$ to the southwest. Site 15, also in Carmagnola, had specimens of $P$.(S.) clarkii but these were found harboring specimens of B. italica and B. parasita, and not the expected C. mesochoreus. This is the first site and record of native Branchiobdella species being found in the wild on an exotic crayfish host in Europe. The observation has established that an imported crayfish is acceptable to Branchiobdella species as an alternative host.

\section{DISCUSSION}

Virtually all of the crayfish examined in northern Italy have been observed to support branchiobdellidans, but most people do not see the worms when the crayfish is healthy. However, when the crayfish become ill, an examination usually finds branchiobdellidans present on the crayfish and most often on the host's gills. This condition was called "branchiobdellidosis" by Mazzarelli 


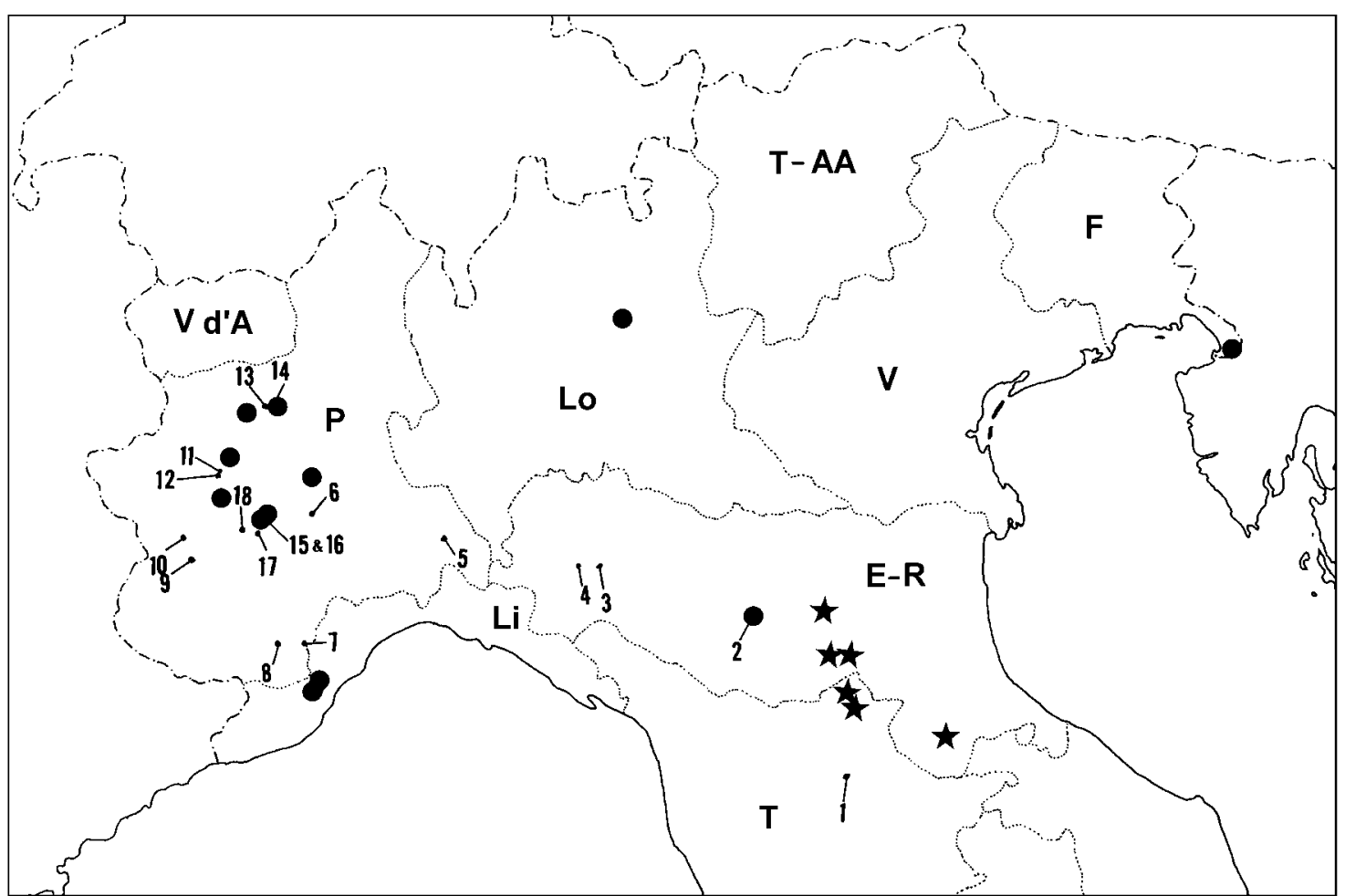

Fig. 1. Distribution of collection sites reported in this paper are shown with Arabic numerals, sites referenced in Nobile et al. (1995) indicated with stars, sites referenced in Gelder et al. (1994) indicated by discs, and the regions are abbreviated as follows: V d'A, Valle d'Aosta; P, Piemonte; Lo, Lombardia; E-R, Emilia-Romagna; T-AA, Trentino-Alto Adige; V, Veneto; F, Friuli; Li, Liguria; T, Toscana.

(1906). It is alleged that the branchiobdellidans cause chronic damage to the host's gills and this is what leads to the eventual death of the crayfish. This ignores the most probable cause of illness being one or more kinds of microscopic pathogens (Alderman \& Polglase 1988), rather than the easily recognizable worms on the ailing crayfish. The continued use of "branchiobdellidosis", primarily in Europe, should be discouraged as the convenient term tends to mask further investigation and treatment of the true illness-causing pathogen.

In some northern Italian regions the health of $A$. pallipes populations appears to be generally good (Ferri et al. 1986, Pascutto et al. 1991, Salvidio et al. 1993) with some of these populations actually growing. Recognizing that not all crayfish populations in the region are robust, only a few individuals were taken from each site in the survey to ensure that the intrinsic rate of natural increase (INRI) was not adversely affected. Specimens of $B$. italica were found on the protected, ventral surfaces of $A$. pallipes wherever they were collected, and this agrees with the reports by Gelder et al. (1994) and Nobile et al. (1995) from the region (Fig. 1). However, B. parasita were reported in the present survey from only two sites, both in the Piemonte Alps, and these were fewer than in the previous studies. Specifi- cally, reports of $B$. parasita from the Apennines include five by Nobile et al. (1995) near sites 1 and 2, and those of Gelder et al. (1994) at Endine, Lombardia and at Nirano, Emilia-Romagna, near sites 2. The third species in the region, $B$. hexodonta, has been reported from Endine, Lombardia, and Nirano, Emilia-Romagna (Gelder et al. 1994), and various rivers in Emilia-Romagna and Toscana (Nobile et al. 1995), although none were recovered in our survey. No explanation can be offered at this time to account for the low numbers of $B$. parasita and not finding any $B$. hexodonta.

The first report of an exotic branchiobdellidan, $C$. mesochoreus, in northern Italy came from specimens of $P$. (S.) clarkii collected from the Stream Venesima di Fortepasso near the Cascina Timavo in Carmagnola, Torino Province on 11 September 1989 (Gelder et al. 1994). Subsequent collections of red crayfish with $C$. mesochoreus in the area include sites 16 and 17, and at Villastellone about $8 \mathrm{~km}$ north of Carmagnola (Gelder et al. 1994). Finding specimens of P.(S.) clarkii at site 15 carrying one native and one endemic species of Branchiobdella, but no $C$. mesochoreus, was unexpected. The nearest location of $A$. pallipes carrying Branchiobdella sp. was at site 18 in Casalgrasso, near the confluence of the Rivers Po and Varaita, $7 \mathrm{~km}$ West of 
Carmagnola. The most likely explanation for the two species of Branchiobdella on P.(S.) clarkii is that during the latter's contact with $A$. pallipes, specimens of $B$. parasita displaced the smaller, $C$. mesochoreus. Although other explanations are possible and the phenomenon should be investigated, consideration should be given for the stated hypothesis.

Adult specimens of $A$. pallipes usually measure 6 to $8 \mathrm{~cm}$ from the tail to the claw tip, compared to the P.(S.) clarkii which grows to 10 to $12 \mathrm{~cm}$ long. A confrontation between the two crayfish would start with P.(S.) clarkii locking chaelae with $A$. pallipes followed by a degree of dismemberment or death of the latter. This would provide ample opportunity for $B$. parasita and $B$. italica to pass onto the new host. Branchiobdellidans in North America have been observed to transfer from one crayfish to another when their chaelae are locked together (Gelder, unpub. obs.). Specimens of mature $C$. mesochoreus measure about $4 \mathrm{~mm}$ long compared to $B$. parasita's commanding length of $10 \mathrm{~mm}$. The displacement of $C$. mesochoreus would remove a possible predator to $B$. italica which measures only $2 \mathrm{~mm}$ in length.

The magnitude of the commercial introductions of exotic crayfish species around the world was reviewed by Hobbs et al. (1989). Since then Delmastro (1992a,b) has reported two exotic North American species of crayfish, $P$.(S.) clarkii and $O$. limosus, in northern Italy, and both are well know hosts of branchiobdellidans in North America (Gelder 1991). Although some information has been collected on the branchiobdellidans where $A$. pallipes and P.(S.) clarkii interact, nothing is known about branchiobdellidan populations and comparable interactions between $O$. limosus and A. pallipes in Lago d'Iseo, Lombardia (Delmastro 1992a). A practical reason for studying the interactions of the endemic and exotic crayfish is that $O$. limosus can be a vector for Aphanomyces astaci causing "crayfish plague" (Laurent 1988: 352,353 ) and that $P$. (S.) clarkii is considered a possible vector (Huner 1988: 261). To be more accurate, the concern should be to prevent a re-introduction of "crayfish plague" into northern Italy. A fact frequently forgotten is that the disease was introduced into Europe from North America through northern Italy in 1860 (Huner 1994: 199). Presumably the pathogen killed all but the most isolated populations of $A$. pallipes in the region and then, due to the lack of any more hosts, all of the infective, free-swimming zoospores died (Huner 1994: 201). Once the pathogen's life-cycle had been broken, the surviving $A$. pallipes populations were free to recolonize the old habitats. It has taken over 100 years for the recovery to achieve the current, stock situation reported earlier. Constant monitoring for native and exotic crayfish and their symbionts is wise as it ensures that pathogens can be identified before damage is caused to the endemic stocks, and that non-patho- genic organisms do not raise false fears in the delicacyeating human population.

\section{CONCLUSIONS}

Wherever the native crayfish, A. pallipes, was found in northern Italy, it was associated with the endemic branchiobdellidan, B. italica. A fewer specimens of $B$. parasita were found at two sites in the Piemonte Alps. The population of North American Louisiana red swamp crayfish, P.(S.) clarkii, with the introduced branchiobdellidan C. mesochoreus first found in 1989 in the Carmagnola area continues to survive. In addition, the red crayfish has proven to be an acceptable host for the native branchiobdellidans, B. italica and B. parasita.

\section{ACKNOWLEDGMENTS}

The field assistance and collection of branchiobdellidans by P. Andreani, G.B. Avalle, M. Evangelista, E. Giovenino, M. Iaconelli and D. Turletti are gratefully recognized. This project was in part supported by a Mini-Grant from the University of Maine at Presque Isle to S. R. Gelder, and the portion conducted by J. N. Rayburn was used to fulfill the research component for the Research Methods in Science course at University of Maine at Presque Isle, and our thanks to Dr Andea M. Gorman for her constructive critisms of the manuscript.

\section{REFERENCES}

Alderman D.J. \& J.L. Polglase. 1988. Pathogens, parasites and commensals. In: D.M. Holdich \& R.S. Lowery (Eds.), Freshwater crayfish: biology, management and exploitation. University Press, Cambridge, U.K.: 167-212.

Boshko, E.G. 1983. Small worms dwelling on river crayfish of some water bodies in the Ukraine. Vestn. zool., 7: 13-20.

Canegallo, M.A. 1928. Una nuova specie di BranchiobdellaBranchiobdella italica. Atti Soc. ital. Sci. Nat. Museo civ. Milano, 67: 214-224.

Delmastro, G.B. 1992a. Il gambero americano Orconectes $l i$ mosus (Rafinesque), un nuovo decapode neartico nelle acque dolci del Nord Italia. Natura Bresciana, Ann. Mus. civ. Sci. nat., Brescia, 27: 171-174.

Delmastro, G.B. 1992b. Sull'acclimatazione del gambero della Louisiana Procambarus clarkii (Girard, 1852) nelle acque dolci italiane (Crustacea: Decapoda: Cambaridae). Pianura - suppl. Provincia Nuova, 4: 5-10.

Ferri, M., L. Sala \& P. Tongiorgi. 1986. Fauna ittica delle Province di Modena e Reggio Emilia. Federazione Italiana Pesca Sportiva e Attività Subacque, Provincia di Modena: $87 \mathrm{pp}$.

Franzén, A. 1962. Notes on the morphology and histology of Xironogiton instabilia (Moore 1893) (Fam. Branchiobdellidae) with special reference to the muscle cells. Zool. Bidr. Uppsala, 35: 369-383.

Gelder, S.R. 1991. New location reports of Nearctic branchiobdellidans (Annelida: Clitellata). Can. Field-Nat., 105: 390-391.

Gelder, S.R., 1996. A review of the taxonomic nomenclature and a checklist of the species of the Branchiobdellae (Annelida: Clitellata). Proc. biol. Soc. Wash., 109: 653-663.

Gelder, S.R., G.B. Delmastro \& M. Ferraguti. 1994. A report on branchiobdellidans (Annelida: Clitellata) and a taxonomic key to the species in northern Italy, including the first record of Cambarincola mesochoreus on the intro- 
duced American red swamp crayfish. Boll. Zool., 61: 179183.

Halgoš, J. 1972. Beitrag zur kenntnis der Ektoparasitischen würmer der ordnung Branchiobdellida in der Slowakei (Annelida, Clitellata). Ac. Rer. Natur. Mus. Nat. Slov, Bratislava, 18: 63-69.

Hobbs, H.H. III, J.P. Jass \& J.V. Huner. 1989. A review of global crayfish introductions with particular emphasis on two North American species (Decapoda, Cambaridae). Crustaceana, 56: 299-316.

Huner, J.V. 1988. Procambarus in North America and elsewhere. In: D.M. Holdich \& R.S. Lowery (Eds), Freshwater crayfish: biology, management and exploitation. University Press, Cambridge, U.K.: 239-261.

Huner, J.V. 1994. Freshwater crayfish aquaculture. Food Products Press, New York: 312 pp.

Karaman S.M. 1970. Beitrag zur Kenntnis der europäischen Branchiobdelliden (Clitellata, Branchiobdellidea). Int. Revue ges. Hydrobiol., 55: 325-333.

Kozarov, G., P. Michailova \& M. Subchev. 1972. Studies on the Branchiobdellidae (Oligochaeta, Annelida) of Bulgaria. Annu. Univ. Sofia Kliment Ochridski- Fac. Biol., 64: 77-89.

Laurent, P.J. 1988. Austropotamobius pallipes and A. torrentium, with observations on their interaction with other species in Europe. In: D. M. Holdich \& R. S. Lowery (Eds.), Freshwater crayfish: biology, management and exploitation. University Press, Cambridge, U.K.: 341-364.

Mazzarelli, G. 1903. La "Branchiobdellosi" dei gamberi. L'Aquicoltura Lombarda, 5: 1-10.

Mazzarelli, G. 1906. Su di alcune malattie di pesci e gamberi osservate in Lombardia. Atti del 3 Congresso Nazionale della Pesca: 259-296.

Nesemann, H. 1994. The epizoic leeches found on crayfishes of the basin of the Upper Danube (Austria, Germany) with an identification key to the European species (Clitellata, Branchiobdellida). Lauterbornia, 19: 79-93.

Nobile, L., S. Giannetto, M. Trentini \& G. Canestri Trotti. 1994. Diffusione di Branchiobdella spp. (Oligochaeta: Branchiobdellidae) in Emilia-Romagna e studio al SEM di Branchiobdella pentodonta italica. Parassitologia, 36, Suppl. 1: 96.

Nobile, L., S. Giannetto, M. Trentini, G. Canestri Trotti \& R. Restani. 1995. Indagine sulla diffusione di Branchiobdella spp. (Annelida, Branchiobdellidae) in gamberi d'acqua dolce (Austropotamobius pallipes italicus) dell'Appennino Tosco-Emiliano. Boll. soc. Ital. Patol., 16: 26-33.

Pascutto T., B. Maffeo \& R. Vanzi. 1991. Censimento preliminare di Austropotamobius pallipes Le. Alcune vallate delle Prealpi Biellesi. Riv. Piem. St. Nat., 12: 216-219.

Pierantoni, U. 1906a. Osservazioni sui Branchiobdella Odier. Anпu. mus. zool. univ. Napoli (new series), 2(4): 1-10.

Pierantoni, U. 1906b. Osservazioni sul genere Branchiobdella Odier. Riv. Mensile Pesca Milano, 8: 1-11.

Pop, V. 1965. Systematische revision der europaischen Branchiobdelliden (Oligochaeta). Zool. Jahrb. abt. Syst. Oekol. Geogr. Tiere, 92: 219-238.

Salvidio S., P. Cresta \& D. Doria. 1993. Preliminary survey on the distribution of the freshwater crayfish Austropotamobius pallipes in Liguria, N.W. Italy. Crustaceana, 65: 218221.

Subchev, M.A. 1984. On Hungarian Branchiobdellids (Oligochaeta: Branchiobdellidae). Misc. Zool. Hungarica, 2: 4750.

Timm, T. 1987. Aquatic Oligochaeta of the northwestern part of the USSR. Academy of the Estonian SSR: $299 \mathrm{pp}$.

van der Land, J. 1978. Branchiobdellidae (Annelida incertae sedis). In: J. Illies (Ed.). Limnofauna Europea. 2nd ed. Gustav Fischer Co., New York: 532 pp.

Wojtas, F. 1964. Notes on the family Branchiobdellidae (Oligochaeta) of the River Grabia. Prz. Zool., 8: 149-151. 